\title{
Iron isotopes in acid mine waters and iron-rich solids from the Tinto-Odiel Basin (Iberian Pyrite Belt, Southwest Spain)
}

\author{
M. Egal a, F. Elbaz-Poulichet ${ }^{a, *}$, C. Casiot a, M. Motelica-Heino ${ }^{\text {, }}$, P. Négrel ${ }^{b}$, O. Bruneel a, \\ A.M. Sarmiento ${ }^{c}$, J.M. Nieto ${ }^{c}$ \\ a Laboratoire Hydrosciences, UMR 5569, Université Montpellier 1 \& 2, CNRS-IRD, Place E. Bataillon, 34095 Montpellier cedex 05, France \\ b BRGM, Orléans, France \\ c Departamento de Geología, Universidad de Huelva. Av. Fuerzas Armadas s/n 21071 Huelva, Spain
}

\section{A B S T R A C T}

The isotopic composition of $\mathrm{Fe}$ was determined in water, Fe-oxides and sulfides from the Tinto and Odiel Basins (South West Spain). As a consequence of sulfide oxidation in mine tailings both rivers are acidic (1.45 $\mathrm{bpH} \mathrm{b} 3.85$ ) and display high concentrations of dissolved Fe (up to $420 \mathrm{mmol} \mathrm{l}^{-1}$ ) and sulphates (up to $1190 \mathrm{mmol} \mathrm{l}^{-1}$.

The $\delta^{56} \mathrm{Fe}$ of pyrite-rich samples from the Rio Tinto and from the Tharsis mine ranged from $-0.56 \pm 0.08 \%$ to $+0.25 \pm 0.1 \%$. $\delta^{56} \mathrm{Fe}$ values for $\mathrm{Fe}$-oxides precipitates that currently form in the riverbed varied from $-1.98 \pm 0.10 \%$ to $1.57 \pm 0.08 \%$. Comparatively narrower ranges of values $(-0.18 \pm 0.08 \%$ and $+0.21 \pm 0.14 \%$ ) were observed in their fossil analogues from the Pliocene-Pleistocene and in samples from the Gossan (the oxidized layer that formed through exposure to oxygen of the massive sulfide deposits) (- $0.36 \pm 0.12 \%$ o to $0.82 \pm 0.07 \%$ ). In water, $\delta^{56} \mathrm{Fe}$ values ranged from $-1.76 \pm 0.10 \%$ o to $+0.43 \pm 0.05 \%$.

At the source of the Tinto River, fractionation between aqueous Fe(III) and pyrite from the tailings was less than would be expected from a simple pyrite oxidation process. Similarly, the isotopic composition of Gossan oxides and that of pyrite was different from what would be expected from pyrite oxidation. In rivers, the precipitation of Fe-oxides (mainly jarosite and schwertmannite and lesser amounts of goethite) from water containing mainly (more than 99\%) Fe(III) with concentrations up to $372 \mathrm{mmol} \mathrm{l}^{-1}$ causes variable fractionation between the solid and the aqueous phase $\left(-0.98 \% \mathrm{~b} \Delta^{56} \mathrm{Fe}_{\text {solid-water }} \mathrm{b} 2.25 \%\right)$. The significant magnitude of the positive fractionation factor observed in several $\mathrm{Fe}$ (III) dominated water may be related to the precipitation of $\mathrm{Fe}$ (III) sulphates containing phases.

Keywords:

Fe isotopes

Acid mine drainage

Iberian Pyrite Belt

\section{Introduction}

$\mathrm{Fe}$ is the fourth most abundant element on Earth. It is an essential element for most living organisms. It is used as an electron donor or acceptor in numerous microbiological metabolisms especially those involving acidophilic organisms (Ehrlich, 1996; Amils et al., 2007). Fe is also a key micronutrient in the limitation of oceanic production and thus plays a direct role in the control of $\mathrm{CO}_{2}$ assimilation by phytoplankton (Martin and Fitzwater, 1988; Martin, 1990; Coale et al., 1996).

Fe isotopes are a good tool to improve our understanding of $\mathrm{Fe}$ cycling and have been used in many scientific fields as reported in the review of Dauphas and Rouxel (2006). Non redox reactions can fractionate Fe isotopes (Anbar et al., 2000), but major effects are due to redox processes (Johnson et al., 2002; Schauble et al., 2001). Fractionation can be predicted theoretically (Polyakov and Mineev,

\footnotetext{
* Corresponding author. Tel.: +33 467143931; fax: +33 467144774.

E-mail address: felbaz@univ-montp2.fr (F. Elbaz-Poulichet).
}

2000; Schauble et al., 2001; Anbar et al., 2005; Polyakov et al., 2007). The theoretical approach of Anbar et al. (2005), based on the density functional theory, predicts a fractionation of $3 \%$ at $25{ }^{\circ} \mathrm{C}$ for the equilibrium fractionation between $\left[\mathrm{Fe}\left(\mathrm{H}_{2} \mathrm{O}\right)_{6}\right]^{3+}$ and $\left[\mathrm{Fe}\left(\mathrm{H}_{2} \mathrm{O}\right)_{6}\right]^{2+}, \mathrm{Fe}$ (III) being isotopically heavier than $\mathrm{Fe}(\mathrm{II})$, which is in good agreement with the experimental data of Johnson et al. (2002) and Welch et al. (2003).

The possible fractionation of $\mathrm{Fe}$ isotopes during biologically mediated reactions and the observation of rather homogeneous isotopic composition in low $\mathrm{C}$ and $\mathrm{S}$ clastic rocks compared to that of chemically precipitated sediments (Beard and Johnson, 1999; Beard and Johnson, 2004) paved the way for Fe biosignatures, though the picture was shown to be more complex that originally thought (Anbar et al., 2000; Anbar, 2004). With the exception of magnetotatic bacterial oxidation (Mandernack et al., 1999), Fe isotope fractionation has been experimentally demonstrated for all biologically mediated Fe reactions including extracellular reductive dissolution of hematite (Beard et al., 2003), extracellular dissolution of ferrihydrite (Beard and Johnson, 1999; Beard et al., 2003), anoxygenic photosynthesis of 
ferrihydrite by photoautotrophic bacteria (Croal et al., 2004), dissolution of hornblende in presence of bacteria (Brantley et al., 2004). However, $\mathrm{Fe}$ isotope fractionation has also been observed during abiotic processes such as abiotic Fe(II) oxidation (Bullen et al., 2001), isotopic exchange between $\mathrm{Fe}$ (II) and Fe(III) (Skulan et al., 2002; Welch et al., 2003), Fe(III) precipitation (Bullen et al., 2001; Skulan et al., 2002; Beard and Johnson, 2004; Balci et al., 2006), Fe(III) dissolution (Brantley et al., 2004).

Most Fe isotope data for natural environments concern solid samples including meteorites and lunar samples (Beard and Johnson, 1999; Poitrasson et al., 2004, Poitrasson and Freydier, 2005). Particular attention has been paid to the Fe isotope composition of Banded Iron Formations (BIFs) (Johsnson et al., 2003; Dauphas et al., 2004, 2007; Yamaguchi et al., 2005), black shales (Rouxel et al., 2005), oceanic crust (Rouxel et al., 2003), ferromanganese crust and nodules (Levasseur et al., 2004; Chu et al., 2006), hydrothermal deposits (Markl et al., 2006; Dideriksen et al., 2006).

An increasing number of studies are now considering the fractionation between water and solids in natural environments such as oceanic hydrothermal systems (Sharma et al., 2001; Severmann et al., 2004; Dauphas and Rouxel, 2006), shelf sediments and porewaters (Severmann et al., 2006), rivers and sediments (Fantle and DePaolo, 2004; Berquist and Boyle, 2006). However the number of data on the $\mathrm{Fe}$ isotope composition of natural waters remains limited. Yet this knowledge is important to better understand the biogeochemical processes that fractionate Fe isotopes in nature.

Fe-rich acidic water also called acid mine drainage (AMD) is produced upon oxidation of pyrite in mining residues. The formation of iron stromatolite-like structures is common in AMD (Brake et al., 2002, 2004; Morin et al., 2003) and is linked to microbial activity, which plays a major role in the oxidation of $\mathrm{Fe}$ and in the precipitation of the Fe-rich solids (Ferris et al., 2004). These modern stromatolites are very similar to those of Late Archean-Early Proterozoic BIFs. AMD may thus be studied as a model for early Earth and extraterrestrial environments (Fang et al., 2007). With the exception of the study of Herbert and Schippers (2008), few data on the isotopic composition of $\mathrm{Fe}$ in acid mine environments have been reported to date.

The Tinto and Odiel Rivers drain the central and eastern part of the Iberian Pyrite Belt, which has the largest known concentration of massive sulfide deposits in the world. Pyrite oxidation is still taking place in the huge mining spoil heaps that resulted from a long history (5000 years) of mining (Leblanc et al., 2000). As a consequence, the waters of both rivers are strongly affected by AMD and display extremely high $\mathrm{Fe}$ concentrations (up to a few hundreds of $\mathrm{mmol} \mathrm{l}^{-1}$ ) and low $\mathrm{pH}$ values (2.5 to 3.5) from the mining area to the estuary (ca. $50 \mathrm{~km}$ ) (Braungardt et al., 2003). The system is currently being studied as a terrestrial analogue for the planet Mars because of the abundance of $\mathrm{Fe}$ and the occurrence of jarosite which resembles that at the Martian Meridiani Planum site (Fairen et al., 2004; FernandezRemollar et al., 2005; Amils et al., 2007).

The objective of this study was to assess the variability of $\mathrm{Fe}$ isotope composition in relation to the main processes affecting $\mathrm{Fe}$ cycling in this $\mathrm{Fe}(\mathrm{II})-\mathrm{Fe}(\mathrm{III})$-pyrite-sulphates-rich system.

Iron isotope composition was determined in the water of the Tinto and Odiel Rivers, in the Fe sulfides of the mining wastes, in the Fe-rich solids that are currently being precipitated from the water, and in similar Fe-oxide precipitates that have been preserved in the PliocenePleistocene river terraces. In parallel, dissolved Fe concentrations (including total, $\mathrm{Fe}(\mathrm{II})$ and $\mathrm{Fe}(\mathrm{III})$ ) were determined. The mineralogical composition of the Fe-rich solids in this system was also analysed.

\section{Site description}

The Iberian Pyrite Belt (IPB) forms part of the South Portuguese Zone, which comprises the southernmost zone of the Iberian Variscan
Belt. The IPB has been reported as one of the largest massive sulfide provinces in the world (Leistel et al., 1998; Sáez et al., 1999; Tornos, 2006), containing more than one hundred individual massive sulfide deposits with original reserves being estimated to exceed 1700 million tons scattered over an area about $250 \mathrm{~km}$ in length and $40 \mathrm{~km}$ in width extending from Seville (Spain) to south of Lisbon (Portugal) (Fig. 1). Two contrasting styles of mineralization can be recognized in the IPB suggesting two different geological settings: shale-hosted exhalative deposits in the southern part of the area, and volcanic-hosted deposits in the northern part formed by stratabound replacement of felsic volcanic rocks. Most of the deposits formed over a short time span, from the Late Devonian to the Early Carboniferous. Some of the sulfide deposits have been exposed at the surface at least since the Miocene, and have consequently undergone extensive oxidation processes, developing a thick cover of iron oxides and hydroxides known as "Gossan", (Pomiès et al., 1998; Nieto et al., 2003).

The metallic ore, which consists of massive bodies of iron and copper sulphides, has been mined since the Third Millennium BC (Leblanc et al., 2000; Nocete et al., 2005), leaving numerous abandoned mining wastes that contain mainly pyrite.

The area is drained by the Tinto and Odiel Rivers. The Odiel River (length: $140 \mathrm{~km}$, surface of the basin: $2300 \mathrm{~km}^{2}$ ) has an average annual flow of about $460 \mathrm{Mm}^{3} \mathrm{yr}^{-1}$. The Tinto River (length: $100 \mathrm{~km}$, surface of the basin: $720 \mathrm{~km}^{2}$ ) has an average annual flow of $90 \mathrm{Mm}^{3}$. $\mathrm{yr}^{-1}$. Except for the upper Odiel River, which is located upstream from the mines, all the water bodies in the area are acidic $(\mathrm{pH}=1.45-3.85)$ and contain extremely high concentrations of $\mathrm{Fe}$ and associated heavy metals and sulphate (Olias et al., 2004; Ferris et al., 2004; Sanchez-Espana et al., 2005).

Despite such extreme conditions, the Tinto and Odiel waters are host to a diverse biota of eukaryotes and prokaryotes (Lopez-Archilla et al., 2001; Zettler et al., 2002; Sabater et al., 2003; Gonzalez-Toril et al., 2003; Aguilera et al., 2006). These organisms probably promote the precipitation of the Fe-rich solids that are ubiquitously encountered in the riverbeds around biological remains (Fernandez-Remolar et al., 2005). In the Pliocene (N 500,000 years) terraces of the Tinto River, similar structures are observed that can be considered as fossil analogues of modern stromatolites (Amils et al., 2007).

\section{Materials and methods}

\subsection{Sample collection}

Four surveys were carried out from 2003 to 2006 . Samples for Fe isotope analysis were taken in July 2003 and July 2006. The locations of the sampling stations are shown in Fig. 1. Water samples were taken in several acid streams rising in the vicinity of former mining areas and in the mainstream of the Tinto and Odiel Rivers. Three samples (TP-1, TP-2, TP-3) were taken in what is generally considered as the source region of the Tinto River. TP-2 was taken immediately (less than $1 \mathrm{~m}$ ) below the outlet of the pyrite tailings stock. TP-1 was taken in another branch of the river at a few hundred meters approximately from the source and has already undergone geochemical modification relative to the source water. TP-3 was sampled downstream from the junction of the TP-1 and TP-2 streams.

Solid samples representing the major types of iron-rich material found in the Tinto and Odiel basins were also collected. Ferruginous solids from old river terraces were taken near Nerva, and at stations ISL and PC (Fig. 1); samples of pyrite were collected in the Tharsis mining district, and from Peña del Hierro mine (Rio Tinto mining district), and Gossan samples were collected in the Tharsis mining district. Different facies of recent sediments - laminated concretions, ferruginous crust and gel-like precipitates - were sampled in the effluents flowing from mine galleries or spoil heaps, and in the mainstream of the Tinto and Odiel Rivers. 


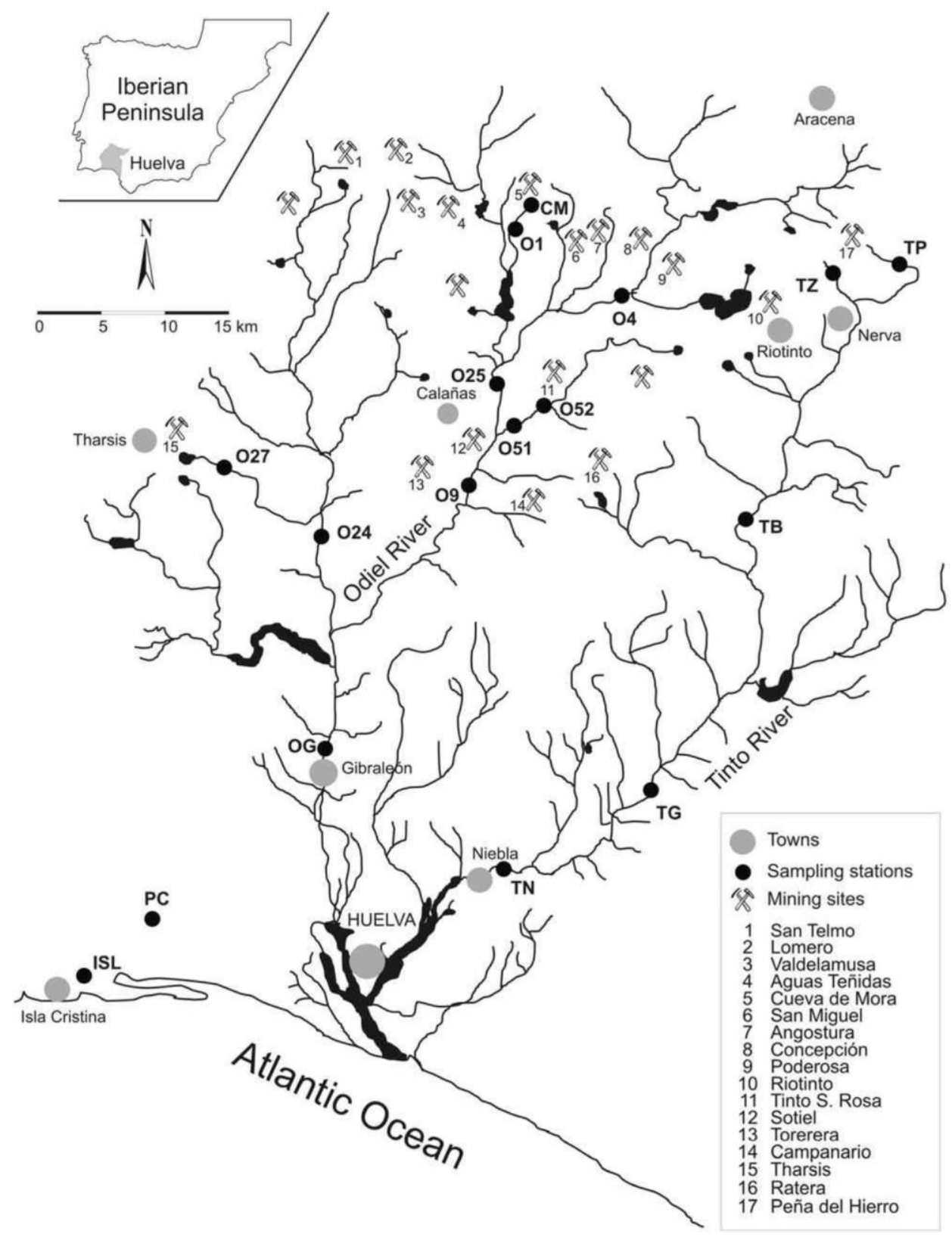

Fig. 1. Map of the study area showing the main mines and the sampling stations in the Tinto and Odiel watersheds.

3.2. Determination of physicochemical parameters of the water and solids

The $\mathrm{pH}$, temperature and the redox potential (Eh) were measured in the field with an Ultrameter ${ }^{\mathrm{TM}}$, Model 6P (Myron L Company, Camlab, Cambridge) equipped with a $\mathrm{pH}$ sensor. Dissolved oxygen $\left(\mathrm{O}_{2 \mathrm{~d}}\right)$ was measured with CHEMets ${ }^{\circledR}$ tests (CHEMetrics, Calverton, USA) based on colorimetric detection after reaction of $\mathrm{O}_{2 \mathrm{~d}}$ with indigo carmine for the range $0-12 \mu \mathrm{g} \mathrm{g}^{-1}$ and with rhodazine $\mathrm{D}$ for $0-$ $1 \mu \mathrm{g} \mathrm{g}^{-1}$.

Water samples were filtered in the field through $0.22 \mu \mathrm{m}$ Millipore membranes mounted on Sartorius polycarbonate filter holders. One aliquot was immediately acidified to $\mathrm{pH} 1$ with $\mathrm{HNO}_{3}(14.5 \mathrm{M})$ and stored at $4{ }^{\circ} \mathrm{C}$ for the determination of total dissolved $\mathrm{Fe}\left(\mathrm{Fe}_{T}\right)$. Another aliquot was taken for determination of $\mathrm{Fe}$ (II). It was buffered to $\mathrm{pH} 4.5$ with an ammonium acetate/acetic acid buffer immediately after filtration and $\mathrm{Fe}(\mathrm{II})$ was complexed by adding $1 \mathrm{ml}$ of a $0.5 \%(\mathrm{w} / \mathrm{w})$ 1,10-phenanthrolinium chloride solution to $10 \mathrm{ml}$ of sample (Rodier et al., 1996). Fe(II) was analysed using spectrophotometry at $510 \mathrm{~nm}$. The detection limit was $0.2 \mathrm{mg} \mathrm{l}^{-1}$ and precision was better than $5 \%$.

$\mathrm{Fe}_{T}$ was determined by Flame Atomic Absorption Spectrometry (FAAS). Dissolved Fe(III) was calculated by difference between $\mathrm{Fe}_{T}$ and $\mathrm{Fe}(\mathrm{II})$.

The main mineralogy of solid samples was determined at the Central Research Services of the University of Huelva using a Bruker D8 Advance X-ray diffractometer. The pulverized samples were irradiated with $\mathrm{CuKa}$ radiation at $40 \mathrm{kV}$ and $30 \mathrm{~mA}$, scanning between $2^{\circ}$ and $70^{\circ}$ with a step interval of 0.05 (2৩).

\subsection{Isotope measurements}

In the first step, solid samples were completely dissolved with $\mathrm{HCl} /$ $\mathrm{HF}(5: 1)$ on a hot plate $\left(80{ }^{\circ} \mathrm{C}, 24 \mathrm{~h}\right)$ followed by $\mathrm{HNO}_{3} / \mathrm{H}_{2} \mathrm{O}_{2}(5: 1)$ $\left(80^{\circ} \mathrm{C}, 24 \mathrm{~h}\right)$, evaporated to dryness and resuspended in $10 \mathrm{ml}$ of $\mathrm{HNO}_{3}$ $(3 \%)$. The purification procedure used for water and dissolved solids is similar to that described by Balci et al. (2006). After oxidation with a 
Table 1

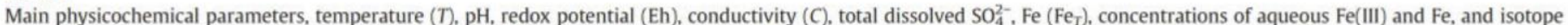
composition in water, laminated concretions (LC) and gel-like precipitates (GL) from the Tinto and Odiel basin

\begin{tabular}{|c|c|c|c|c|c|c|c|c|c|c|c|c|c|c|c|c|c|}
\hline \multirow{3}{*}{\multicolumn{2}{|c|}{$\begin{array}{l}\text { Date } \\
\text { Odiel Basin }\end{array}$}} & \multirow[t]{4}{*}{$T^{\circ} \mathrm{C}$} & \multirow[t]{4}{*}{$\mathrm{pH}$} & \multirow{4}{*}{$\begin{array}{l}C \mu \mathrm{S} \\
\mathrm{cm}^{-1}\end{array}$} & \multirow{4}{*}{$\begin{array}{l}\mathrm{SO}_{4}^{2-} \\
\mathrm{mmol}^{-1}\end{array}$} & Eh & $\mathrm{O}_{2}$ & & $\mathrm{Fe}(\mathrm{II})$ & $\mathrm{Fe}(\mathrm{III})$ & Water & & $\delta^{56} \mathrm{Fe}$ & 6) LC & GL & & Main Fe mineral \\
\hline & & & & & & & ppm & $\begin{array}{l}\mathrm{mmol} \\
\mathrm{I}^{-1}\end{array}$ & $\begin{array}{l}\mathrm{mmol} \\
\mathrm{I}^{-1}\end{array}$ & $\begin{array}{l}\mathrm{mmol} \\
\mathrm{I}^{-1}\end{array}$ & Mean \pm & $2 S D$ & Mean & 2SD & Mean \pm & & \\
\hline & & & & & & & & & & & & & & & & & \\
\hline Cueva d & la Mora mi & & & & & & & & & & & & & & & & \\
\hline $\mathrm{CM}$ & $01 / 07 / 03$ & 27.6 & 3.14 & 4576 & & 0.62 & 10 & 5.49 & 0.48 & 5.01 & -1.12 & 0.07 & 1.12 & 0.05 & 0.78 & 0.12 & Sh \\
\hline CM & $01 / 07 / 04$ & 28.6 & 3.04 & 4575 & 43 & & 10 & 4.59 & 0.13 & 4.46 & -1.11 & 0.10 & & & $-0.68 *$ & 0.13 & \\
\hline $\mathrm{CM}$ & $01 / 07 / 06$ & 29.3 & 2.89 & 3400 & & 0.69 & $>12$ & 2.13 & 2.98 & 0.02 & -1.76 & 0.10 & & & & & \\
\hline Monte I & omero mine & & & & & & & & & & & & & & & & \\
\hline 01 & $01 / 07 / 03$ & 25.6 & 2.9 & 4542 & & 0.71 & & 3.09 & 0.33 & 2.76 & & & & & & & \\
\hline 04 & $01 / 07 / 03$ & 23.8 & 2.76 & 5710 & & 0.72 & 8 & 2.66 & 0.29 & 2.37 & & & & & & & \\
\hline 04 & $01 / 07 / 04$ & 34.2 & 2.39 & 8006 & 89 & & 12 & 3.80 & 0.04 & 3.76 & & & & & & & \\
\hline 04 & $01 / 10 / 05$ & 21.9 & 2.75 & 4376 & & 0.72 & 11 & 1.86 & 1.21 & 0.64 & & & & & & & \\
\hline 04 & $01 / 07 / 06$ & 29.3 & 2.72 & 4650 & & 0.78 & $>12$ & 2.29 & 0.66 & 1.63 & -1.71 & 0.14 & & & -1.98 & 0.10 & \\
\hline Odiel Ri & & & & & & & & & & & & & & & & & \\
\hline $\mathrm{O} 25$ & & 29.2 & 2.82 & 3956 & & 0.74 & 8 & 0.31 & 0.13 & 0.18 & & & & & & & \\
\hline Santa $R$ & sa mine & & & & & & & & & & & & & & & & \\
\hline O51 & $01 / 07 / 03$ & 23.8 & 2.82 & 2906 & & 0.77 & 8 & 0.3 & 0.08 & 0.17 & & & & & & & \\
\hline 052-1 & $01 / 07 / 03$ & 24.1 & 3.32 & 3853 & & 0.60 & 8 & 11.0 & 0.57 & 10.4 & -1.03 & 0.09 & 1.10 & 0.07 & 1.22 & 0.14 & \\
\hline 052-1 & $01 / 07 / 04$ & 21.8 & 3.17 & 3543 & 31 & & 3.5 & 12.2 & 0.34 & 11.9 & & & & & & & \\
\hline $052-1$ & $01 / 07 / 06$ & 22.4 & 3.3 & 3280 & & 0.57 & 3.5 & 16.9 & 13.6 & 3.27 & -1.49 & 0.10 & & & & & \\
\hline $052-2$ & $01 / 07 / 03$ & 21.3 & 3.5 & 3812 & & 0.50 & 3.5 & 11.2 & 0.57 & 10.6 & & & 1.57 & 0.08 & & & Sh, Gt \\
\hline $052-2$ & $01 / 07 / 06$ & 29.3 & 3.08 & 3810 & & 0.60 & 7 & 15.6 & 13.2 & 2.39 & & & & & 0.68 & 0.10 & \\
\hline Sothiel & nine & & & & & & & & & & & & & & & & \\
\hline 09 & $01 / 07 / 03$ & 32.1 & 2.94 & 3243 & & 0.73 & 8 & 0.19 & 0.11 & 0.08 & & & & & & & \\
\hline 09 & $01 / 07 / 04$ & 25.4 & 2.17 & 3049 & & & 10 & 0.20 & 0.20 & 0.01 & & & & & & & \\
\hline 09 & $01 / 10 / 05$ & 19.7 & 2.97 & 3544 & & 0.75 & 9 & 0.48 & 0.34 & 0.14 & & & & & & & \\
\hline Tharsis & nine & & & & & & & & & & & & & & & & \\
\hline $027-1$ & $01 / 07 / 03$ & 33.5 & 3.1 & 8077 & & 0.70 & $>12$ & 0.17 & 0.02 & 0.15 & & & 0.79 & 0.08 & 0.41 & 0.14 & Sh, Jt, Gt \\
\hline $027-1$ & $01 / 07 / 04$ & 32.5 & 2.38 & 15490 & 225 & & 9 & 28.6 & 0.12 & 28.5 & & & & & & & \\
\hline $027-1$ & $01 / 10 / 05$ & 19.9 & 2.57 & 10260 & & 0.71 & $>12$ & 19.5 & 4.68 & 14.8 & & & & & & & \\
\hline O27-1 & $01 / 07 / 06$ & 25 & 2.47 & 11900 & & 0.69 & $>12$ & 26.0 & 25.0 & 1.02 & -1.70 & 0.10 & & & & & \\
\hline $027-2$ & $01 / 07 / 03$ & 32.1 & 2.56 & 16150 & & 0.71 & & 31.8 & 1.36 & 30.4 & -0.96 & 0.07 & -0.16 & 0.09 & & & \\
\hline Oraque & River & & & & & & & & & & & & & & & & \\
\hline 024 & $01 / 07 / 03$ & 29.6 & 2.85 & 2245 & & 0.70 & - & 0.11 & 0.11 & 0.00 & -0.31 & 0.13 & & & -1.30 & 0.02 & Sh \\
\hline $\mathrm{O} 24$ & $01 / 10 / 05$ & 18 & 2.84 & 4115 & & 0.75 & 9 & 0.80 & 0.32 & 0.48 & & & & & & & \\
\hline 024 & $01 / 07 / 06$ & 24.3 & 2.93 & 1319 & & 0.76 & 7 & 0.27 & 0.14 & 0.13 & -1.28 & 0.10 & & & & & \\
\hline San Telr & & & & & & & & & & & & & & & & & \\
\hline 029 & $01 / 10 / 05$ & 19.4 & 2.6 & 12010 & & 0.73 & & 17 & 3.04 & 13.5 & & & & & & & \\
\hline 029 & $01 / 07 / 06$ & 30.76 & 2.44 & 15080 & & 0.68 & $>12$ & 33 & 28.3 & 5.09 & -1.74 & 0.10 & -1.03 & 0.10 & -0.84 & 0.10 & \\
\hline 029 & $01 / 07 / 06$ & 30.76 & 2.44 & 15080 & & 0.68 & $>12$ & 33 & 28.3 & 5.09 & & & -0.98 & 0.10 & & & \\
\hline Gibralec & nOG & & & & & & & & & & & & & & & & \\
\hline OG & $01 / 07 / 04$ & 30.1 & 3.24 & 1588 & 9 & & 6 & 0.04 & 0.03 & 0.01 & & & & & & & \\
\hline Tinto B. & & & & & & & & & & & & & & & & & \\
\hline Pena de & Hierro & & & & & & & & & & & & & & & & \\
\hline TP-1 & $01 / 07 / 04$ & 35.5 & 2.43 & 9558 & 99 & & 10 & 20.5 & 0.47 & 20.02 & -0.37 & 0.12 & & & -0.69 & 0.15 & $\mathrm{Jt}$ \\
\hline TP-1 & $01 / 10 / 05$ & 22.8 & 3.2 & 8121 & & 0.60 & 9 & 16.9 & 16.1 & 0.77 & & & & & & & \\
\hline TP-1 & $01 / 07 / 06$ & 22.7 & 2.75 & 7570 & & 0.68 & $>12$ & 16.9 & 10.3 & 6.63 & -0.76 & 0.10 & & & & & \\
\hline TP-2 & $01 / 07 / 04$ & 35 & 1.45 & 26980 & 1191 & & 11 & 372 & 0.24 & 372 & 0.43 & 0.05 & & & & & \\
\hline TP-2 & $01 / 10 / 05$ & 20.6 & 1.81 & 27020 & & 0.74 & & 420 & 26.3 & 394 & & & & & & & \\
\hline TP-2 & $01 / 07 / 06$ & & 1.64 & & & 0.77 & & & & & -0.23 & 0.10 & & & & & \\
\hline TP-3 & $01 / 10 / 05$ & 23.3 & 2.12 & 18060 & & 0.72 & & 177 & 18.84 & 158 & & & & & & & \\
\hline TP-3 & $01 / 07 / 04$ & 34 & 1.81 & 20670 & 616 & & 11 & 226 & 0.39 & 226 & & & & & & & \\
\hline Zaranda & & & & & & & & & & & & & & & & & \\
\hline $\mathrm{TZ}$ & $01 / 07 / 04$ & 33.9 & 2.26 & 13110 & 17 & & 12 & 60 & 0.73 & 59.4 & -0.72 & 0.06 & 1.14 & 0.10 & & & Jt, Hy Jt \\
\hline $\mathrm{TZ}$ & $01 / 10 / 05$ & 23.9 & 2.77 & 11350 & & 0.61 & 11 & 54 & 6.53 & 47.4 & & & & & & & \\
\hline $\mathrm{TZ}$ & $01 / 07 / 06$ & 27.2 & 2.72 & 8340 & & 0.66 & $>12$ & 39 & 30.9 & 7.68 & -0.88 & 0.10 & & & & & \\
\hline Berrocal & & & & & & & & & & & & & & & & & \\
\hline TB & $01 / 07 / 03$ & 29.6 & 2.43 & 9605 & & 0.84 & - & 36.7 & 1.04 & 35.7 & & & & & & & \\
\hline TB & $01 / 07 / 04$ & 27.8 & 2.07 & 9508 & 139 & & $>12$ & 39.2 & 0.02 & 39.1 & -0.36 & 0.07 & & & & & \\
\hline TB & $01 / 10 / 05$ & 18.3 & 2.55 & 2690 & & 0.70 & $>12$ & 6.0 & 2.73 & 3.30 & & & & & & & \\
\hline $\mathrm{TB}$ & $01 / 07 / 06$ & 23.3 & 2.48 & 5180 & & 0.85 & $>12$ & 17.7 & 0.29 & 17.4 & -1.15 & 0.10 & & & -1.16 & 0.10 & \\
\hline Gadea & & & & & & & & & & & & & & & & & \\
\hline TG & $01 / 07 / 04$ & 26.9 & 2.15 & 3318 & 17 & & $>12$ & 1.36 & 0.35 & 1.01 & -0.19 & 0.12 & -0.71 & 0.07 & -0.97 & 0.10 & $\mathrm{Jt}, \mathrm{Gt}$ \\
\hline TG & $01 / 10 / 05$ & 17.9 & 2.38 & 3710 & & 0.76 & $>12$ & 9.78 & 0.89 & 8.89 & & & & & & & \\
\hline TG & $01 / 07 / 06$ & 29.4 & 2.64 & 1508 & & 0.80 & 11 & 2.21 & 0.12 & 2.10 & & & & & & & \\
\hline Niebla & & & & & & & & & & & & & & & & & \\
\hline $\mathrm{TN}$ & $01 / 07 / 03$ & 31.8 & 2.66 & 3320 & & 0.77 & & 1.63 & 0.13 & 1.49 & & & & & & & \\
\hline $\mathrm{TN}$ & $01 / 07 / 04$ & 26 & 2.74 & 2228 & 10 & & & 0.14 & 0.14 & & & & & & & & \\
\hline $\mathrm{TN}$ & $01 / 10 / 05$ & 18 & 2.55 & 3828 & & 0.79 & $>12$ & 9.06 & 0.30 & 8.77 & & & & & & & \\
\hline $\mathrm{TN}$ & $01 / 07 / 06$ & 24.8 & 2.69 & 1259 & & 0.78 & $>12$ & 1.80 & 0.19 & 1.62 & & & & & & & \\
\hline
\end{tabular}

$\mathrm{Sh}=$ Schwertmannite; $\mathrm{Gt}=$ Goethite; Jt=Jarosite; $\mathrm{Hy} \mathrm{Jt}=$ hydronian jarosite.

SD: standard deviation, number of replicate analysis $n=40$.

*Crust sample.

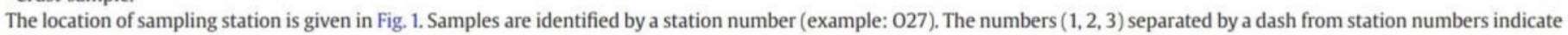
different seepages. 
few drops of concentrated $\mathrm{H}_{2} \mathrm{O}_{2}$, the sample was purified using $2 \mathrm{ml}$ of resin (RE Spec resin Eichrom Technologies Inc., IL, USA). Around $10 \mathrm{ml}$ of the sample (diluted to an average of $5 \mathrm{mg} \mathrm{l}^{-1} \mathrm{Fe}$ ) was loaded on a column with the resin. Sample matrix was removed and eluted with $10 \mathrm{ml}$ of $\mathrm{HNO}_{3}(8 \mathrm{~N})$ and the Fe was eluted with $10 \mathrm{ml}$ of $\mathrm{HNO}_{3}(3 \%)$. Iron isotopes $\left({ }^{54} \mathrm{Fe},{ }^{56} \mathrm{Fe}\right)$ were measured with a Neptune double focusing sector field multiple collector ICP-MS (Thermo-Finnigan, Bremen, Germany). This high resolution enables iron isotopes to be measured without isobaric interferences from polyatomic species with the peak-shoulder method developed by Weyer and Schwieters (2003).

The determination of isotopic ratios of samples was made with external calibration using the reference material IRMM-14 (IRMM, Geel, Belgium), after internal normalisation with $\mathrm{Cu}$ isotopes (spiked at $1 \mathrm{mg} \mathrm{l}^{-1}$ in the samples and standards). The external precision was evaluated by analysing the reference material IRMM-14 with external calibration with IRMM-14. The external reproducibility was $0.06 \%$ $\delta^{56} \mathrm{Fe}$ (2 standard deviations). It was similar to what obtained by double-spiking (Balci et al., 2006). The accuracy of the method was determined similarly. The 2-SD for individual samples was determined from the raw data. Each measurement consisted of 4 blocks of 10 cycles of $4 \mathrm{~s}$ duration. Thus the number of replicate was 40 per sample.

$\delta^{56} \mathrm{Fe}$ is defined by the following equation:

$\delta^{56} \mathrm{Fe}=\left[\left({ }^{56} \mathrm{Fe} /{ }^{54} \mathrm{Fe}_{\text {sample }}\right) /\left({ }^{56} \mathrm{Fe} /{ }^{54} \mathrm{Fe}\right.\right.$ IRMM $\left.)-1\right] \times 1000$

\section{Results}

\subsection{Aqueous chemistry}

Data are listed in Table 1. The temperature of water ranged from 17.9 to $35.5^{\circ} \mathrm{C}\left(21.3\right.$ to $35.5^{\circ} \mathrm{C}$ in the waters analysed for Fe isotopes). The dissolved oxygen content ranged from 3.5 to $12 \mathrm{mg} \mathrm{l}^{-1}$, reflecting oxic conditions. All water samples were acidic with $\mathrm{pH}$ values ranging from 1.45 for the water emerging from the pyrite wastes (TP-2 station) to 3.24 at the $O G$ station located at the entry of the estuary.

The highest $\mathrm{SO}_{4}^{2-}$ (up to $1190 \mathrm{mmol} \mathrm{I}^{-1}$ ) and $\mathrm{Fe}_{T}$ concentrations (up to $420 \mathrm{mmol} \mathrm{I}^{-1}$ ) and the lowest $\mathrm{pH}$ values (down to 1.45) were observed at the TP2 station in water seeping from the pyrite-rich
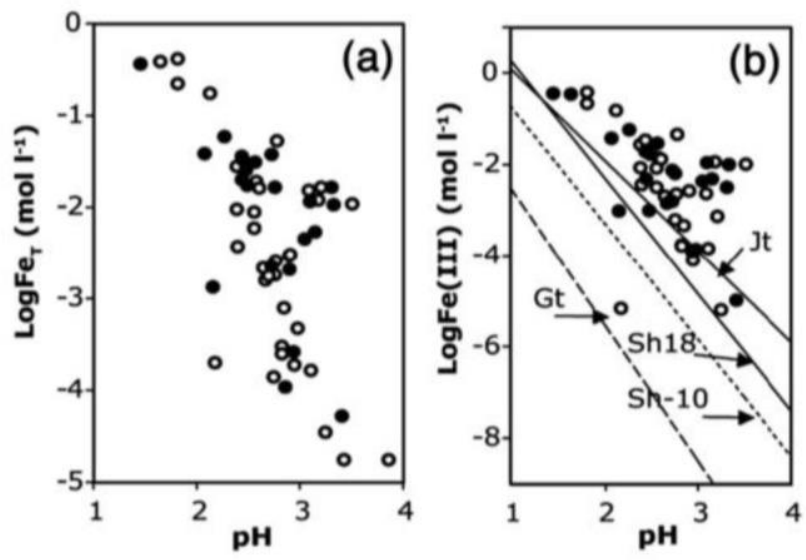

Fig. 2. Concentrations of total dissolved $\mathrm{Fe}\left(\mathrm{Fe}_{\mathrm{T}}\right.$ ) (a) and $\mathrm{Fe}$ (III) (b) versus pH. Samples analysed for Fe isotopes are in black. Theoretical solubility lines for schwertmannite $(\mathrm{Sh})$, goethite $(\mathrm{Gt})$ and jarosite (Jt) are also represented. The following reactions and constants are used: Schwertmannite ( $\mathrm{Sh}-10): \mathrm{Fe}_{8} \mathrm{O}_{8}(\mathrm{OH})_{4.4}\left(\mathrm{SO}_{4}\right)_{1.8}+20.4 \mathrm{H}^{+}=8 \mathrm{Fe}^{3+}+1.8$ $\mathrm{SO}_{4}^{2-}+12.4 \mathrm{H}_{2} \mathrm{O}$; LogKs=10.5, Yu et al. (1999). Schwertmannite (Sh-18): $\mathrm{Fe}_{8} \mathrm{O}_{8}(\mathrm{OH})_{4.8}$ $\left(\mathrm{SO}_{4}\right)_{1.6}+20.8 \mathrm{H}^{+}=8 \mathrm{Fe}^{3+}+1.6 \mathrm{SO}_{4}^{2-}+12.8 \mathrm{H}_{2} \mathrm{O} ;$ LogKs=18, Bigham et al. (1996). Goethite (Gt): $\mathrm{FeOOH}+3 \mathrm{H}^{+}=\mathrm{Fe}^{3+}+2 \mathrm{H}_{2} \mathrm{O} ;$ LogKs $=0.5$, Parkhurst and Appelo (1999). Jarosite (Jt): $\mathrm{KFe}_{3}\left(\mathrm{SO}_{4}\right)_{2}(\mathrm{OH})_{6}+6 \mathrm{H}^{*}=\mathrm{K}^{+}+3 \mathrm{Fe}^{3+}+2 \mathrm{SO}_{4}^{2-}+6 \mathrm{H}_{2} \mathrm{O} ;-14.8$, Parkhurst and Appelo (1999). ${ }^{*}$ Calculation have been made for $\mathrm{Log}\left(\mathrm{SO}_{4}^{2-}\right)=-2.74$, which represents a bottom limit for $\mathrm{SO}_{4}^{2-}$ activity in AMD (higher $\mathrm{SO}_{4}^{2-}$ activities would shift down the solubility lines).

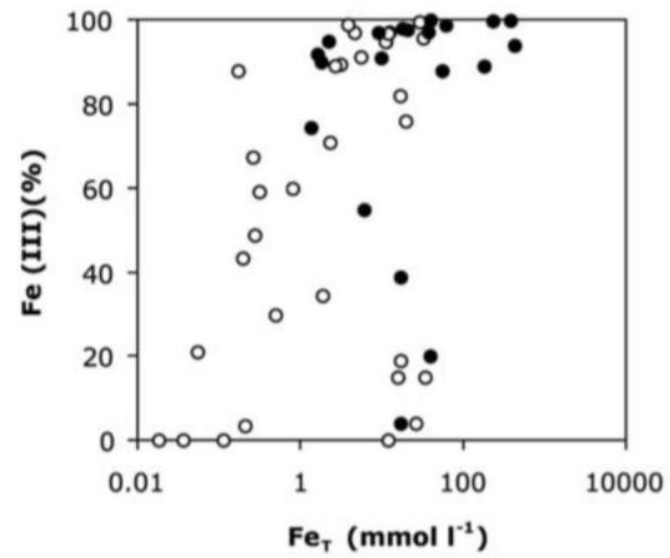

Fig. 3. Percentage of $\mathrm{Fe}$ (III) in solution as a function of total dissolved $\mathrm{Fe}\left(\mathrm{Fe}_{\mathrm{T}}\right)$. Samples analysed for Fe isotopes are in black.

tailings stock at Peña de Hierro (Table 1). The concentrations of $\mathrm{Fe}_{T}$ and $\mathrm{Fe}$ (III) generally decreased with an increase in $\mathrm{pH}$ (Fig. 2). The percentage of $\mathrm{Fe}(\mathrm{III})$ in solution reached nearly $100 \%$ in the water emerging from the pyrite waste (TP-2 station) and dropped to $0 \%$ at the entry to the river estuary (OG and TN stations, Fig. 1). It decreased with decreasing $\mathrm{Fe}_{T}$ concentrations (Fig. 3). Only a few samples from the 2006 survey did not follow this pattern but had a lower percentage of $\mathrm{Fe}$ (III) than that observed in previous surveys.

The water was supersaturated with regards to both jarosite and schwertmannite (Fig. 2) in agreement with previous results obtained by Acero et al. (2006). According to Sanchez-Espana et al. (2007) supersaturation is due to high oxidation rates of $\mathrm{Fe}\left(5.5 \times 10^{-6}\right.$ to $\left.4 \times 10^{-7} \mathrm{~mol} \mathrm{I}^{-1} \mathrm{~s}^{-1}\right)$ and comparatively low precipitation rates of Feoxides $\left(1.7 \times 10^{-6}\right.$ to $\left.10^{-7} \mathrm{~mol} \mathrm{l}^{-1} \mathrm{~s}^{-1}\right)$.

Results of speciation calculations using the thermodynamic equilibrium calculation program CHESS (van der Lee and de Windt, 2002) for three representative qualities of water are shown in Table 2. In the source water (TP2 station) characterized by low $\mathrm{pH}$ (1.45), and high $\mathrm{SO}_{4}^{2-}\left(1191 \mathrm{mmol} \mathrm{l}^{-1}\right)$ and $\mathrm{Fe}_{T}\left(372 \mathrm{mmol} \mathrm{l}^{-1}\right)$ concentrations, $\mathrm{Fe}$ occurred predominantly (about 67\%) as Fe(III)-sulphatocomplexes. At the TZ station, which displayed slightly higher $\mathrm{pH}(2.26)$ and lower $\mathrm{SO}_{4}^{2-}\left(17 \mathrm{mmol} \mathrm{I}^{-1}\right)$ and $\mathrm{Fe}_{T}\left(60 \mathrm{mmol} \mathrm{I}^{-1}\right)$ concentrations, the majority of $\mathrm{Fe}$ was in the form of $\mathrm{Fe}$ (III)-hydroxocomplexes. At the $\mathrm{O} 29$ station $\left(\mathrm{pH}=2.6 ;\left[\mathrm{Fe}^{2+}\right]=3.04 \mathrm{mmol} \mathrm{I}^{-1},\left[\mathrm{Fe}^{3+}\right]=13.5 \mathrm{mmol} \mathrm{l}^{-1}\right)$, most of the Fe (about 69\%) was in the form of $\mathrm{Fe}$ (II)-sulphatocomplexes.

\subsection{Characteristics of stream bed sediments}

Fe-rich precipitates were ubiquitous in the riverbeds except at the TP-2 station. They contained an average of $40 \%$ Fe. Three different

Table 2

Typical speciation of $\mathrm{Fe}$ in water from the Tinto and Odiel basins

\begin{tabular}{|c|c|c|c|c|c|}
\hline \multirow{2}{*}{$\frac{\mathrm{TP2}(07 / 2004)}{\mathrm{Fe}(\mathrm{III})}$} & \multirow[t]{2}{*}{ mol\% } & $029(10 / 2005)$ & \multirow[t]{2}{*}{$\mathrm{mol} \%$} & TZ (07/2004) & \multirow[t]{2}{*}{$\mathrm{mol} \%$} \\
\hline & & $\mathrm{Fe}$ (III) & & $\mathrm{Fe}$ (III) & \\
\hline$\left[\mathrm{Fe}\left(\mathrm{SO}_{4}\right)\right]^{2-}$ & 52.5 & {$[\mathrm{Fe}]^{3+}$} & 8 & {$[\mathrm{Fe}]^{3+}$} & 37 \\
\hline$[\mathrm{Fe}]^{3+}$ & 28.5 & {$[\mathrm{Fe}(\mathrm{OH})]^{2 *}$} & 6.3 & {$[\mathrm{Fe}(\mathrm{OH})]^{2+}$} & 34 \\
\hline$\left[\mathrm{Fe}\left(\mathrm{SO}_{4}\right)\right]^{*}$ & 15 & {$\left[\mathrm{Fe}_{3}(\mathrm{OH})_{4}\right]^{5+}$} & 0.3 & {$\left[\left.\mathrm{Fe}_{3}(\mathrm{OH})_{4}\right|^{5 *}\right.$} & 17 \\
\hline$\left[\mathrm{Fe}(\mathrm{OH})_{2}\right]^{2+}$ & 2.8 & {$\left[\mathrm{Fe}(\mathrm{OH})_{2}\right]^{+}$} & 0.2 & {$\left[\mathrm{Fe}(\mathrm{OH})_{2}\right]^{+}$} & 9.4 \\
\hline \multirow[t]{6}{*}[\mathrm{Fe}(\mathrm{OH})]{$^{2+}$} & 1.1 & {$\left[\mathrm{Fe}\left(\mathrm{SO}_{4}\right)\right]^{*}$} & 0.2 & {$\left[\mathrm{FeSO}_{4}\right]^{+}$} & 0.7 \\
\hline & & & & {$\left[\mathrm{Fe}(\mathrm{OH})_{2}\right]^{+}$} & 0.7 \\
\hline & & & & {$\left[\mathrm{Fe}\left(\mathrm{SO}_{4}\right)_{2}\right]^{-}$} & 0.1 \\
\hline & & $\mathrm{Fe}$ (III) & & $\mathrm{Fe}$ (II) & \\
\hline & & {$[\mathrm{Fe}]^{2+}$} & 69.5 & {$[\mathrm{Fe}]^{2+}$} & 1 \\
\hline & & {$\left[\mathrm{FeSO}_{4}\right]$} & 16 & {$\left[\mathrm{FeSO}_{4}\right]$} & 0.2 \\
\hline
\end{tabular}

The values used for calculations are listed in Table 1 (at the 029 station, the concentration of $\mathrm{SO}_{4}^{2-}$ was estimated from the relationship between conductivity and $\mathrm{SO}_{4}^{2-}$ ). 

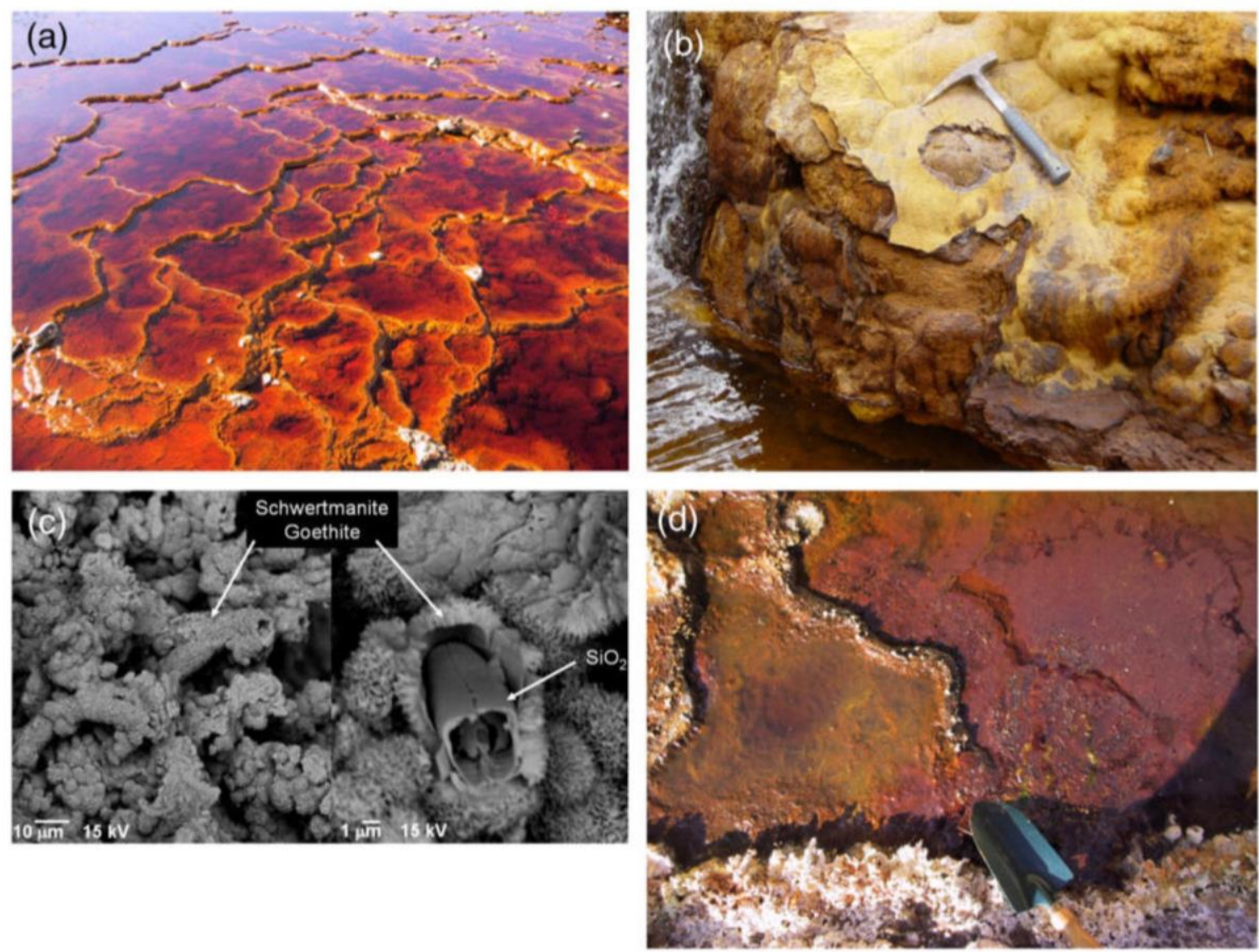

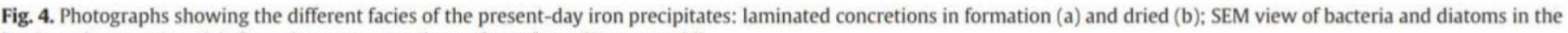
laminated concretions (c): ferruginous crust at the surface of standing water (d).

facies of precipitates could be distinguished. Some concretions were laminated (Fig. 4a, b). Scanning electron photographs show dead or living biological debris such as diatoms encrusted in the precipitates (Fig. 4c). Gel-like precipitates are fine ochres that, unlike laminated concretions, do not agglomerate. The third type of precipitate facies was recovered in the biofilm formed at the surface of stagnant water (Fig. 4d).

As expected from CHESS calculations and in agreement with previous observations in this system (Sanchez-Espana et al., 2005), XRD analysis confirmed the presence of schwertmannite, jarosite, goethite in the precipitates (Table 1).

The different facies did not correspond to systematic mineralogical differences and in some samples more than one mineral was identified. These samples were mainly "laminated concretions", in which the upper part of the sample (up to the first $1 \mathrm{~cm}$ ) was schwertmannite (mainly in the Odiel basin) or jarosite (mainly in the Tinto basin) whereas goethite is observed at greater depths. The mineral transformation can clearly be seen in Fig. 4b (Tinto-Santa Rosa), where the upper, yellow, part of the concretion is schwertmannite that is transformed into goethite forming the dark part of the sediment below the yellow material. In the laboratory, this alteration takes a few months (Acero et al., 2006).

In Gossan samples, Fe minerals consisted mainly in either hematite or goethite. The facies of the iron-rich deposits from the old river terraces strongly resembled the laminated concretions that form nowadays. They can therefore be considered as their fossil equivalents. They displayed different mineralogy characterized by the presence of a goethite matrix with quartz, K-feldspar and rock clasts. This may reflect recrystallisation after deposition.

\subsection{Iron isotope ratios in solids and waters}

The $\delta^{56} \mathrm{Fe}$ values of river water and precipitates are presented in Table 1. The isotope composition of other solids is presented in Table 3. A summary of the data obtained for these solids and comparison with data from the literature are presented in Fig. 5.

Table 3

Fe content, main Fe mineral and iron isotope ratios of source rocks and ancient precipitates from the Tinto-Odiel basin

\begin{tabular}{|c|c|c|c|c|c|c|}
\hline \multirow{3}{*}{$\begin{array}{l}\text { Sample } \\
\text { name }\end{array}$} & \multirow[t]{3}{*}{ Date } & \multirow[t]{3}{*}{ Location } & \multirow{3}{*}{$\begin{array}{l}\frac{\mathrm{Fe}}{\% \text { dry }} \\
\text { wt. }\end{array}$} & \multicolumn{2}{|l|}{$\delta^{56} \mathrm{Fe}$} & \multirow{3}{*}{$\begin{array}{l}\text { Main iron } \\
\text { minerals }\end{array}$} \\
\hline & & & & \multicolumn{2}{|l|}{ \% } & \\
\hline & & & & Mean & $\pm 2 \mathrm{SD}$ & \\
\hline \multicolumn{7}{|c|}{ Pyrite ore body } \\
\hline P-Py & $07 / 03$ & Pena de Hierro & 18 & 0.25 & 0.1 & Py \\
\hline FS-SM1 & $07 / 03$ & Tharsis mine southern vein & 11 & -0.56 & 0.08 & Py \\
\hline FN-SM2 & $07 / 03$ & Tharsis mine northern vein & 10 & -0.47 & 0.1 & Py \\
\hline \multicolumn{7}{|c|}{ Fe-oxides from the Gossan } \\
\hline FS8 & $07 / 03$ & Tharsis mine southern vein & & -0.29 & 0.02 & Gt \\
\hline FS11 & $07 / 03$ & Tharsis mine southern vein & & 0.29 & 0.03 & $\mathrm{Ht}$ \\
\hline FN8 & $07 / 03$ & Tharsis mine northern vein & & 0.82 & 0.07 & Gt \\
\hline FN10 & $07 / 03$ & Tharsis mine northern vein & & 0.37 & 0.02 & $\mathrm{Ht}$ \\
\hline TG & $07 / 03$ & Nerva (transported Gossan) & 53 & -0.36 & 0.12 & \\
\hline \multicolumn{7}{|c|}{ Fossilized laminated concretions } \\
\hline PC & $07 / 04$ & Pinares de Cartaya & 15 & 0.21 & 0.14 & Gt \\
\hline ISL & $07 / 04$ & Islantilla & 18 & -0.18 & 0.08 & Gt \\
\hline
\end{tabular}

Py $=$ pyrite; $\mathrm{Gt}=$ goethite; $\mathrm{Ht}=$ hematite . 


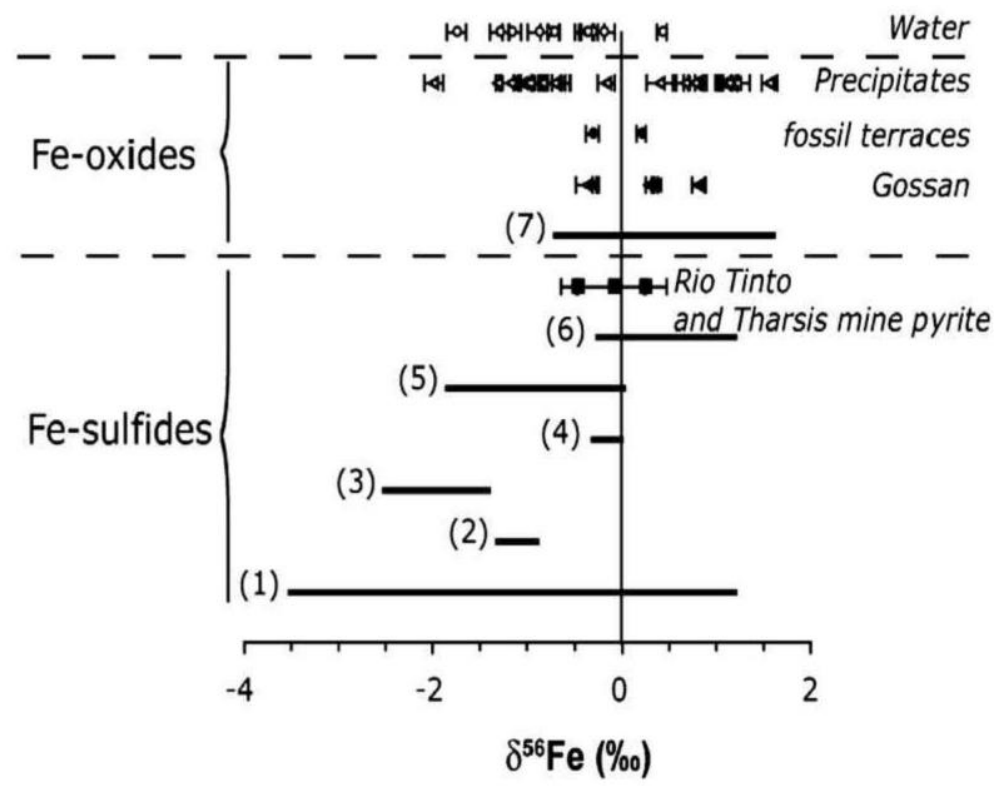

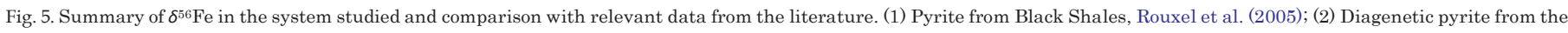

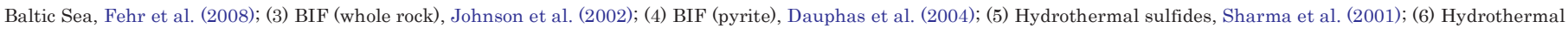
pyrite, Graham et al. (2004); (7) Fe-oxides from BIF, Johnson et al. (2003), Rouxel et al. (2005).
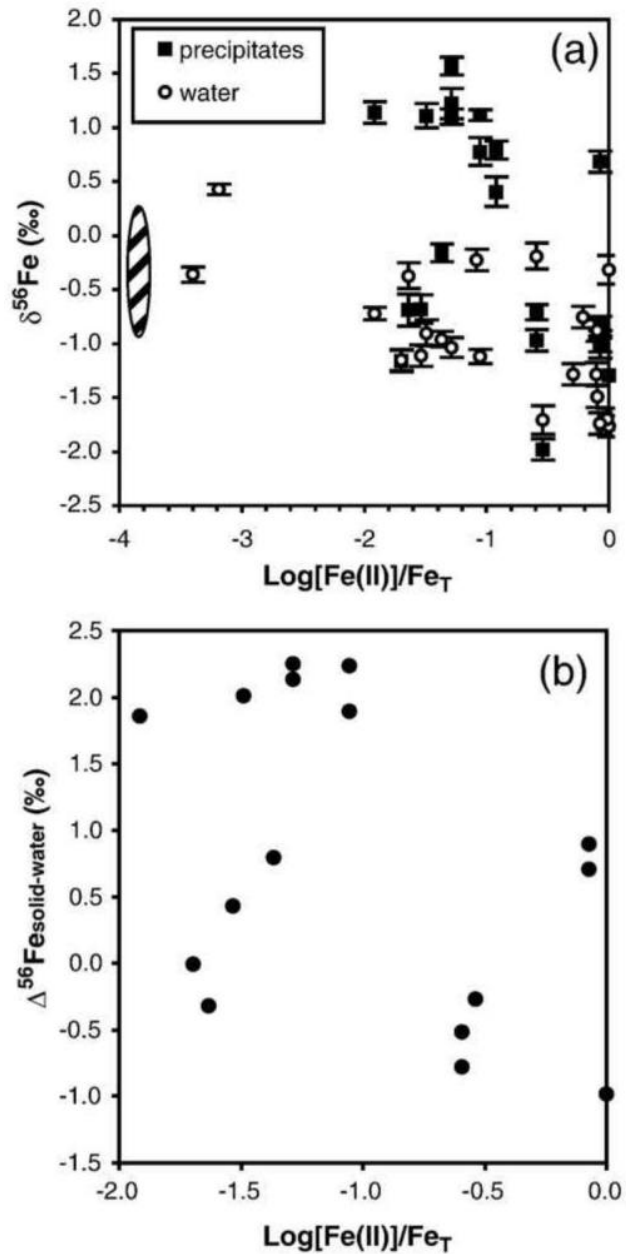

Fig. 6. Fe isotope composition $\left(\delta^{56} \mathrm{Fe}\right)$ of precipitates and water (a) and fractionation factor between water and precipitates $\left(\Delta_{\text {solid-water }}\right)$ (b) versus the logarithm of the aqueous $\mathrm{Fe}(\mathrm{II})$ fraction $\left(\log \left[\mathrm{Fe}(\mathrm{II}) / \mathrm{Fe}_{T}\right]\right.$ ). The hatched area represents the range of $\delta^{56} \mathrm{Fe}$ values in the fossil laminated concretions.
The Fe isotope composition of pyrite, which is the main primary source of $\mathrm{Fe}$ in the system, ranged from $-0.56 \pm 0.08 \%$ to $0.25 \pm 0.10 \%$. As shown in Fig. 5, the range of Fe isotopic compositions reported in the literature for pyrite is quite large. The values observed in this study

compare well with those reported for the massive volcanogenic sulfide deposit of the Grasberg Igneous Complex (Graham et al., 2004).

The river precipitates displayed the largest range of isotopic composition with $\delta^{56} \mathrm{Fe}$ values ranging from $-1.98 \pm 0.10 \%$ (station O4) to $1.57 \pm 0.08 \%$ (station $052-2$ ). Comparatively narrow variations in ${ }^{56} \mathrm{Fe}$ values were encountered in their fossil analogues from river terraces $(-0.18 \pm 0.08 \%$ o to $+0.21 \pm 0.14 \%$ o $)$ and in the iron oxides from the Gossan $(-0.36 \pm 0.12 \%$ o to $0.82 \pm 0.07 \%$ ). These values are within the ranges observed for Fe-oxides from BIFs (Johnson et al., 2003; Rouxel et al., 2005).

The range of ${ }^{56} \mathrm{Fe}$ in gel-like sediments $(-1.98 \pm 0.1 \%$ to $0.68 \pm$ $0.1 \%$ ) was slightly larger than in laminated concretions $(-0.98 \pm 0.1 \%$ o to $1.57 \pm 0.08 \%$ ). The data from the CM station showed that at the same location, the three different sediment facies can have significantly different isotope compositions. However, the whole data set did not provide any evidence for systematic variation in the isotopic composition in relation to the sediment facies.

In water, $\delta^{56} \mathrm{Fe}$ ranged from $-1.76 \pm 0.1 \%$ o to $0.43 \pm 0.05 \%$. The values were generally negative except at the TP- 2 station.

When plotted as a function of the logarithm of the Fe(II) fraction in solution $\left(\mathrm{Log}[\mathrm{Fe}(\mathrm{II})] / \mathrm{Fe}_{T}\right)$, the distribution of isotopic ratios was somewhat scattered. Nevertheless, general trends can be distinguished in the evolution of $\delta^{56} \mathrm{Fe}$ values. In both water and sediments, the Fe isotope ratios tend to decrease with an increase in the Fe(II) fraction in water (Fig. 6). Significant fractionation (up to 2.25\%) between the sediments and the water, favouring the heavier isotope in the solid, was observed generally in $\mathrm{Fe}(\mathrm{III})$ dominated water $\left(\mathrm{Log}[\mathrm{Fe}(\mathrm{II})] / \mathrm{Fe}_{\tau}\right.$ b-1, Fig. 6).

\section{Discussion}

The isotopic composition at the TP-2 station located at the outlet of the tailing stock (less than $1 \mathrm{~m}$ downstream) can be used to assess $\mathrm{Fe}$ fractionation during the generation of AMD in the mine tailings. AMD formation is mainly driven by the oxidation process of sulfidecontaining solids amongst which pyrite is the most abundant at the 
study site. The overall reaction for the oxidation of pyrite has the following form:

$4 \mathrm{FeS}_{2}+15 \mathrm{O}_{2}+10 \mathrm{H}_{2} \mathrm{O} \rightarrow 4 \mathrm{FeOOH}_{(\mathrm{s})}+8 \mathrm{SO}_{4}^{2-}+16 \mathrm{H}^{+}$

In this form, the reaction does not reflect the importance of $\mathrm{Fe}$ (III) that has been shown to be a much more efficient electron acceptor than oxygen (Moses et al., 1987). Indeed the reaction proceeds stepwise according to:

$\mathrm{FeS}_{2}(\mathrm{~s})+14 \mathrm{Fe}^{3+}+8 \mathrm{H}_{2} \mathrm{O} \rightarrow 15 \mathrm{Fe}^{2+}+2 \mathrm{SO}_{4}^{2-}+16 \mathrm{H}^{+}$

$\mathrm{Fe}^{2+}+0.25 \mathrm{O}_{2}+\mathrm{H}^{+} \rightarrow \mathrm{Fe}^{3+}+0.5 \mathrm{H}_{2} \mathrm{O}$

At low $\mathrm{pH}$, abiotic oxidation of Fe is slow (Stumm and Morgan, 1981), and reaction (4), which is the rate-limiting step determining the availability of $\mathrm{Fe}(\mathrm{III})$ (Evangelou, 1995), requires mediation that is generally ensured by acidophilic bacteria that play a central role in the process of pyrite degradation through the oxidation of $\mathrm{Fe}^{2+}$ (Johnson and Hallberg, 2003).

Eventually, Fe(III) can precipitate according to:

$\mathrm{Fe}^{3+}+2 \mathrm{H}_{2} \mathrm{O} \rightarrow \mathrm{FeOOH}_{(\mathrm{s})}+3 \mathrm{H}^{+}$

The data of Polyakov et al. (2007) for pyrite, and of Anbar et al. (2005) for $\left[\mathrm{Fe}\left(\mathrm{H}_{2} \mathrm{O}\right)_{5^{3}}^{3+}\right.$, yields a theoretical fractionation factor $\Delta_{\text {yrite-Fe(III) }}$ of $1.95 \%$ at $25^{\circ} \mathrm{C}$, pyrite being isotopically heavier. Significantly lower values $(-0.18 \%$ in 2004 and $0.48 \%$ in 2006$)$ were obtained at the TP-2 station from the isotopic composition of pyrite (P-py, Table 3), and water. The difference can be explained by the presence of an iron source depleted in ${ }^{56} \mathrm{Fe}$ compared to pyrite. Alternatively, the precipitation of $\mathrm{Fe}$ oxides according to Eq. (5) could favour the enrichment of the aqueous phase in the heavy isotope as suggested by the $\mathrm{Fe}$ (III) precipitation experiments of Balci et al. (2006) in an acidic sulphates-rich medium or those of Skulan et al. (2002) showing that rapid precipitation of hematite from $\mathrm{Fe}$ (III) results in an increase in the $\delta^{56} \mathrm{Fe}$ of $\mathrm{Fe}(\mathrm{III})$.

The isotopic composition of oxides (hematite or goethite) from the Gossan samples of the Tharsis mine ranged from - $0.29 \%$ to $0.82 \%$ o (Table 3). In all cases these values are higher than those observed at the same site for pyrite $\left(-0.56 \%\right.$ o b $\delta^{56} \mathrm{Feb}-0.47 \%$ ), which can be considered as the precursor of the Gossan oxides. This observation of higher $\delta^{56} \mathrm{Fe}$ values in oxides compared to pyrite which is ubiquitous in the rock record (Beard and Johnson, 2004) is rather surprising given the pyrite beta values of Polyakov and Mineev (2000) and Polyakov et al. (2007) which predict a ${ }^{56} \mathrm{Fe}$ depletion of oxides relative to pyrite $\left(\Delta_{\text {hematite-pyrite }}=-3.62 \%, \Delta_{\text {goethite-pyrite }}=-5.69 \%\right.$ o at $\left.25{ }^{\circ} \mathrm{C}\right)$.

The fractionation factors between water and $\mathrm{Fe}$-oxide precipitates vary in a large range $\left(-0.98 \% \mathrm{~b} \Delta^{56} \mathrm{Fe}_{\text {solid-water }}\right.$ b $2.25 \%$ os shown in Fig. 6. The observation of negative or slightly positive factors between $\mathrm{Fe}(\mathrm{III})$ in the solid and in the solution is not surprising. It corroborates the results of the experimental studies. For example, the fractionations reported by Balci et al. (2006) for the precipitation of $\mathrm{Fe}$ (III) from an acidic $(\mathrm{pH} \leq 3.54)$ synthetic solution of $\mathrm{Fe}(\mathrm{III})$-sulphates ranged from $-0.04 \%$ to $-1.46 \%$, favouring the lighter isotope in the solid phase. According to Skulan et al. (2002), the precipitation of hematite from $\mathrm{Fe}(\mathrm{III})$ over $12 \mathrm{~h}$ yielded a kinetic fractionation factor $\Delta^{56} \mathrm{Fe}_{\text {hematite-Fe(III) }}$ of $-1.3 \%$ whereas at slow precipitation rates, slightly positive $\Delta^{56} \mathrm{Fe}_{\text {hematite-Fe(III) values }(0.1 \% \text { ) }}$ corresponding to equilibrium fractionation were observed. The observation of significantly positive fractionation factors between $\mathrm{Fe}$ (III) in the several precipitates from $\mathrm{Fe}(\mathrm{III})$ dominated water is more striking. Fractionation factors of the same order of magnitude (1\%) with preferential incorporation of the heavier isotope have been reported by Bergquist and Boyle (2006) during the coagulation of Fe(III) colloids in the Amazon estuary but this was in water having very different physicochemical conditions compared to the AMD of this study.
In our system, the large range of fractionation may be attributed to Fe-mineral discrimination. To confirm this hypothesis further studies

of $\mathrm{Fe}$ (III) fractionation during the precipitation of pure $\mathrm{Fe}$ (III) oxyhydroxysulphates solids including both crystallized phases such as jarosite and schwertmannite and amorphous phases are necessary.

The isotopic composition of the fossil stromatolites is coherent with that of their modern analogues (Fig. 6). Nevertheless, the wide range of isotopic composition encountered in the modern $\mathrm{Fe}$ (III) precipitates does not enable accurate assessment of the physicochemical conditions that prevailed in the water when the fossil stromatolites formed.

\section{Conclusion}

This study investigated the isotopic fractionations in an acidic (1.4 b pHb 3.2) Fe- and sulphur rich system, the Tinto-Odiel River basin. The isotopic composition of pyrite-rich solids, which are the ultimate source of $\mathrm{Fe}$ in the system, ranges from $-0.56 \pm 0.08 \%$ in the

Tharsis massive sulphide deposit to $0.25 \pm 0.1 \%$ in the Rio Tinto massive sulphide deposit. The isotopic composition of the Fe-oxides from the Gossan ranged from $-0.29 \pm 0.02 \%$ to $0.82 \pm 0.07 \%$.

The fractionation factor between pyrite and oxidized Fe either as aqueous $\mathrm{Fe}$ (III) or in the mineral (goethite or hematite) from the Gossan appears to be systematically lower than what would be expected from theoretical values.

The $\delta^{56} \mathrm{Fe}$ values in the Fe-rich oxides that precipitate from the river water ranged from $-1.98 \pm 0.10 \%$ to $1.57 \pm 0.08 \%$. In water, the range of $\delta^{56} \mathrm{Fe}$ values (from $-1.76 \pm 0.10 \%$ to $+0.43 \pm 0.05 \%$ ) was smaller.

The fractionation factors between the precipitates and the water vary in a large range $\left(-0.98 \% \mathrm{~b} \Delta^{56} \mathrm{Fe}_{\text {solid-water }} \mathrm{b} 2.25 \%\right.$ ), the highest values being observed in $\mathrm{Fe}$ (III) dominated waters. The large range of fractionation factors may reflect a discrimination due to the formation of different Fe-oxides/sulphates minerals. However, analyses of experimentally and naturally produced Fe-oxyhydroxysulphates solids, including pure minerals phases must be carried out in order to confirm this hypothesis.

An $\mathrm{Fe}$ isotope fingerprint in fossil stromatolites was unfortunately not identified which would have enabled us to trace the physicochemical conditions that prevailed at the time of their deposition.

\section{Acknowledgements}

This study was financed by the CNRS (PICS no.2430), the ECODYN and EC2CO programmes (French Ministry of Research, Institut National des Sciences de l'Univers).

\section{References}

Acero, P., Ayora, C., Torrentó, C., Nieto, J.M., 2006. The behavior of trace elements during schwertmannite precipitation and subsequent transformation into goethite and jarosite. Geochim. Cosmochim. Acta 70, 4130-4139.

Aguilera, A., Manrubia, S.C., Gómez, F., Rodríguez, N., Amils, R., 2006. Eukaryotic community distribution and its relationship to water physicochemical parameters in an extreme acidic environment, Río Tinto (Southwestern Spain). Appl. Environ. Microbiol. 72, 5325-5330.

Anbar, A.D., 2004. Iron stable isotopes: beyond biosignatures. Earth Planet. Sci. Lett. 217, 223-236.

Anbar, A.D., Roe, J.E., Barling, J., Nealson, K.H., 2000. Non biological fractionation of iron isotopes. Science $2888,126-128$.

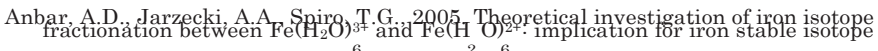
geochemistry. Geochim. Cosmochim. Acta 69, 825-837.

Amils, R., Gonzales-Toril, E., Fernandez-Remollar, D., Gomez, F., Aguilera, A., Rodriguez, N., Malki, M., Garcia-Moyano, A., Fairen, A., de la Fuente, V., Sanz, J.L., 2007. Extreme environments as Mars terrestrial analogs: the Rio Tinto case. Planet. Space Sci. 55, 370-381.

Balci, N., Bullen, T., Witte-Lien, K., Shanks, W., Motelica, M., Mandernack, K., 2006. Iron isotope fractionation during microbially stimulated $\mathrm{Fe}$ (II) oxidation and $\mathrm{Fe}$ (III) precipitation. Geochim. Cosmochim. Acta 70, 622-639.

Beard, B.L., Johnson, C.M., 1999. High precision iron isotope measurements of terrestrial and lunar material. Geochim. Cosmochim. Acta 63, 1653-1660. 
Beard, B., Johnson, C., 2004. Fe isotope variations in the modern and ancient Earth and other planetary bodies. In: Rosso, J.J. (Ed.), Reviews in Mineralogy and Geochemistry, vol. 55, pp. 319-353.

Beard, B.L., Johnson, C.M., Skulan, J.L., Nealson, K.H., Cox, L., Sun, H., 2003. Application of Fe isotopes to tracing the geochemical and biological cycling of Fe. Chem. Geol. 285, 87-117.

Bergquist, B.A., Boyle, E.A., 2006. Iron isotopes in the Amazon River system: weathering and transport signatures. Earth Planet. Sci Lett. 248, 54-68.

Bigham, J.M., Schwertmann, U., Traina, S.J., Winland, R.L., Wolf, M., 1996. Schwertman nite and the chemical modeling of iron in acid sulphates waters. Geochim. et Cosmochim. Acta 60, 2111-2121.

Brake, S.S., Hasiotis, S.T., Dannelly, H.K., Connors, K.A., 2002. Eukaryotic stromatolite builders in acid mine drainage: implications for Precambrian iron formations and oxygenation of the atmosphere? Geology 30, 599-602.

Brake, S.S., Hasiotis, S.R., Dannelly, H.K., 2004. Diatoms in acid mine drainage and their role in the formation of iron-rich stromatolites. Geomicrobiol. J. 21, 331-340.

Braungardt, C., Achterberg, E., Elbaz-Poulichet, F., Morley, N.H., 2003. Metal biogeochemistry in an acidic mine polluted estuarine system in south-west Spain. Appl. Geochem. 18, 1757-1871.

Brantley, S., Liermann, L., Guynn, R., Anbar, A., Icopini, G., Barling, J., 2004. Fe isotopic fractionation during mineral dissolution with and without bacteria. Geochim. Cosmochim. Acta 68, 3189-3204.

Bullen, T.D., White, A.F., Childs, C.W., Vivit, D.V., Schulz, M.S., 2001. Demonstration of significant abiotic iron isotope fractionation in nature. Geology 29 (8), 699-702.

Chu, N.-C., Johnson, C., Beard, B., German, C., Nesbitt, R., Frank, M., Bohn, M., Kubik, P., Usui, A., Graham, I., 2006. Evidence for hydrothermal venting in Fe isotope compositions of the deep Pacific Ocean through time. Earth Planet. Sci. Lett. 245, 202-217.

Coale, K.H., Johnson, K.S., Fitzwater, S., Gordon, M., Taner, S., Chavez, F., Ferioli, L., Sakamoto, C., Rogers, P., Millero, F., Steinberg, P., Nightingale, P., Cooper, D., Cochland, W., Landry, M., Constantinou, J., Rollwagen, G., Trasvina, A., Kudela, R., 1996. A massive phytoplankton bloom induced by an ecosystem-scale iron fertilization experiment in the equatorial Pacific Ocean. Nature 383, 495-501.

Croal, L.R., Johnson, C.M., Beard, B.L., Newman, D.K., 2004. Iron isotope fractionation by Fe(II)-oxidizing photoautotrophic bacteria. Geochim. Cosmochim. Acta 68 (6), $1227-1242$.

Dauphas, N., Rouxel, N., 2006. Mass spectrometry and natural variations of iron isotopes. Mass Spectrometry Reviews 25, 515-550.

Dauphas, N., Zuilen, M., Wadhwa, M., Davis, A., Marty, B., Janney, P., 2004. Clues from Fe isotope variations on the origin of Early Archean BIFs from Greenland. Science 306, $2077-2080$

Dauphas, N., Cates, N., Mojzsis, S., Busigny, V., 2007. Identification of chemical sedimentary protoliths using iron isotopes in the N 3750 Nuvvuagittuq supracrustal belt, Canada. Earth Planet. Sci. Lett. 254, 358-376.

Dideriksen, K., Baker, J.A., Stipp, S.L., 2006. Iron isotopes in natural carbonate minerals determined by MC-ICP-MS with a ${ }^{58} \mathrm{Fe}-54 \mathrm{Fe}$ double spike. Geochim. Cosmochim. Acta, 70 1, 118-132.

Evangelou, V.P., 1995. Pyrite oxidation and its control. CRC Press, New York. 275 pp.

Ehrlich, H., L., 1996. In Geomicrobiology. Marcel Dekker, New York. 719pp.

Fairen, A.G., Fernandez-Remolar, D., Dohm, J.M., Baker, V.R., Amils, R., 2004. Inhibition of carbonate synthesis in acidic oceans on early Mars. Nature 431, 423-426.

Fang, J., Hasiotis, S., Das Gupta, S., Brake, S., Bazylinsky, D., 2007. Microbial biomass and community structure of a stromatolite from an acid mine drainage system as determined by lipid analysis. Chem. Geol. 243, 191-204.

Fantle, M., DePaolo, D., 2004. Iron isotopic fractionation during continental weathering. Earth Planet. Sci. Lett. 228, 547-562.

Fehr, M., Andersson, P., Hälenius, U., Mörth, C.-M., 2008. Iron isotope variations in Holocene sediments of the Gotland Deep, Baltic Sea. Geochim. Cosmochim. Acta 72, 807-826.

Fernandez-Remolar, D., Moris, R., Gruener, J., Amils, R., Knoll, A., 2005. The Rio Tinto Basin, Spain: mineralogy, sedimentary geobiology, and implications for interpretation of outcrop rocks at Meridiani Planum, Mars. Earth Planet. Sci. Lett. 240, 149-167.

Ferris, F.G., Hallbeck, L., Kennedy, C.B., Pedersen, K., 2004. Geochemistry of acidic Rio Tinto headwaters and role of bacteria in solid phase metal partitioning. Chem. Geol. $212(3-4), 291-300$.

Gonzalez-Toril, E., Llobet-Brossa, E., Casamayor, E.O., Amann, R., Amils, R., 2003. Microbial ecology of an extreme acidic environment, the Tinto River. Appl. Environ. Microbiol. 6, 4853-4865.

Graham, S., Pearson, N., Jackson, S., Griffin, W., O'Reilly, S.Y., 2004. Tracing Cu and Fe from source to porphyry: in situ determination of $\mathrm{Cu}$ and $\mathrm{Fe}$ isotopes ratios in sulfides from the Grasberg $\mathrm{Cu}-\mathrm{Au}$ deposit. Chem. Geol. 207, 147-169.

Herbert Jr., R.B., Schippers, A., 2008. Iron isotope fractionnation by biogeochemical processes in mine tailings. Environ. Sci. Technol. 1117-1122.

Johnson, D., Hallberg, K., 2003. The microbiology of acidic mine waters. Res. Microbiol. $154,466-473$.

Johnson, C.M., Skulan, J.K., Beard, N.J., Sun, H., Nealson, K.H., Braterman, P.S., 2002. Isotopic fractionation between $\mathrm{Fe}(\mathrm{III})$ and $\mathrm{Fe}(\mathrm{II})$ in aqueous solution. Earth Planet. Sci. Lett. 195, 141-153.

Johnson, C., Beard, B., Beukes, N., Klein, C., O'Leary, J., 2003. Ancient geochemical cycling in the Earth as inferred from $\mathrm{Fe}$ isotope studies of banded iron formations from the Transvaal Craton. Contrib. Mineral. Petrol. 144, 523-547.

Leblanc, M., Morales, J.A., Borrego, J., Elbaz-Poulichet, F., 2000. A 4500 years old mining pollution in Spain. Econ. Geol. 95, 655-662.

Leistel, J.M., Marcoux, E., Thiéblemont, D., Quesada, C., Sánchez, A., Almodóvar, G.R., Pascual, E., Sáez, R., 1998. The volcanic-hosted massive sulfide deposits of the Iberian Pyrite Belt. Mineralium Deposita 33, 2-30.
Levasseur, S., Frank, M., Hein, J.R., Halliday, A.N., 2004. The global variation in the iron isotope composition of marine hydrogenetic ferromanganese deposits: implications for seawater chemistry? Earth Planet. Sci. Lett. 224, 91-105.

Lopez-Archilla, A.I., Marin, I., Amils, R., 2001. Microbial community composition and ecology of an acidic aquatic environment: the Tinto River, Spain. Microb. Ecol. 41 (1), 20-35.

Mandernack, K.W., Bazylinski, D.A., Shranks, W.C., Bullen, T.D., 1999. Oxygen and iron isotopes studies of magnetite produced by magnetotactic bacteria. Science 285 , $1892-1896$.

Markl, G., von Blanckenburg, F., Wagner, T., 2006. Iron isotope fractionation during hydrothermal ore deposition and alteration. Geochim. Cosmochim. Acta 70, 30113030 .

Martin, J.H., 1990. Glacial-interglacial $\mathrm{CO}_{2}$ change: the iron hypothesis. Paleoceanogr. 5, $1-13$

Martin, J.H., Fitzwater, S.E., 1988. Iron deficiency limits phytoplankton growth in the North-East Pacific subarctic. Nature 331, 341-343.

Morin, G., Juillot, F., Casiot, C., Bruneel, O., Personné, J.C., Elbaz-Poulichet, F., Leblanc, M., Ildefonse, P., Calas, G., 2003. Bacterial immobilization and oxidation of arsenic in acid mine drainage (Carnoulès creek, France): XANES and XRD evidence of As(V) or As(III)-Fe(III) gels and tooeleite. Environ. Sci. Technol. 37, 1705-1712.

Moses, C.O., Nordstrom, D.K., Herman, J.S., Mills, A.L., 1987. Aqueous pyrite oxidation by dissolved oxygen and by ferric iron. Geochim. Cosmochim. Acta 51, 15611571.

Nieto, J.M., Capitán, M.A., Sáez, R., Almodóvar, G.R., 2003. Beudantite: a natural sink for As and $\mathrm{Pb}$ in sulfide oxidation processes. Appl. Earth Sci. 112, 293-296.

Nocete, F., Álex, E., Nieto, J.M., Sáez, R., Bayona, M.R., 2005. An archaeological approach to regional environmental pollution in the South-Western Iberian Peninsula related to Third Millennium BC mining and metallurgy. J. Archaeol. Sci. 32, 15661576.

Olias, M., Nieto, J.M., Sarmiento, A.M., Ceron, J.C., Canovas, C.R., 2004. Seasonal water quality variations in a river affected by acid mine drainage: the Odiel River (South West Spain). Sci. Tot. Env. 333 (1-3), 267-281.

Parkhurst, D.L., Appelo, C.A.J., 1999. User's Guide to PHREEQC (Version 2) - a compute program for speciation, batch-reaction, one-dimensional transport, and inverse geochemical calculations. U.S. Geological Survey Water-Resources Investigation Report 99-4259. Denver, Co., U.S.A.,p. 312.

Poitrasson, F., Freydier, R., 2005. Heavy iron isotope composition of granites determined by high resolution MC-ICP-MS. Chem. Geol. 222, 132-147.

Poitrasson, F., Halliday, A., Lee, D.C., Levasseur, S., Teutsch, N., 2004. Iron isotope differences between Earth, Moon, Mars and Vesta as possible records of contrasted accretion mechanisms. Earth Planet. Sci. Lett. 223, 253-266.

Polyakov, V.B., Mineev, S.D., 2000. The use of Mösbauer spectroscopy in stable isotope geochemisty. Geochim. Cosmochim. Acta 64, 849-865.

Polyakov, V.B., Clayton, R.N., Mineev, S.D., 2007. Equilibrium fractionation factors of minerals: reevaluation from data of nuclear inelastic resonant X-ray scattering and Mössbauer spectroscopy. Geochim Cosmochim. Acta 71, 3833-3846.

Pomiès, C. Cocherie, A., Guerrot, C., Marcoux, E., Lancelot, J., 1998. Assessment of the precision and accuracy of lead-isotope ratios measured by TIMS for geochemical applications: example of massive sulfide deposits (Rio Tinto, Spain). Chem. Geol. $144,137-149$.

Rodier, J., Broutin, J.P., Chambon, P., Champsaur, H., Rodi, L., 1996. L'analyse de l'eau. Dunod, Paris. 1383 pp

Rouxel, O., Dobeck, N., Ludden, J., Fouquet, Y., 2003. Iron isotope fractionation during oceanic crust alteration. Chem. Geol. 202, 155-182.

Rouxel, O., Bekker, A., Edwards, K., 2005. Iron isotope constraints on the Archean and Paleoproterozoic ocean redox state. Science 307, 1088-1091.

Sabater, S., Buchaca, T., Cambra, I., Catalán, I., Guasch, H., Ivorra, N., Muñoz, I., Navarro, E., Real, M., Romaní, A., 2003. Structure and function of benthic algal communities in an extremely acid river. J. Phycol. 39, 481-489.

Sáez, R., Pascual, E., Toscano, M., Almodóvar, G.R., 1999. The Iberian type of volcanosedimentary massive sulfide deposits. Mineralium Deposita 34, 549-570.

Sanchez-Espana, J., Lopez Pamo, E., Santofimia, E., Aduvire, O., Reyes, J., Barettino, D., 2005. Acid mine drainage in the Iberian Pyrite Belt (Odiel river watershed, Huelva, SW Spain): Geochemistry, mineralogy and environmental implications. Appl. Geochem. 20, 1320-1356.

Sanchez-Espana, J., Lopez Pamo, E., Pastor, E., 2007. The oxidation of ferrous iron in acidic mine effluents from the Iberian Pyrite Belt (Odiel Basin, Huelva, Spain): field and laboratory rates. J. Geochem. Explor. 92, 120-132.

Severmann, S., Johnson, C., Beard, B., German, C., Edmonds, H., Chiba, H., Green, D., 2004 The effect of plume processes on the $\mathrm{Fe}$ isotope composition of hydrothermally derived $\mathrm{Fe}$ in the deep ocean as inferred from the Rainbow vent site, Mid-Atlantic Ridge, $36^{\circ} 14^{\prime} \mathrm{N}$. Earth Planet. Sci. Lett. 225, 63-76.

Severmann, S., Johnson, C., Beard, B., McManus, J., 2006. The effect of early diagenesis on the $\mathrm{Fe}$ isotope compositions of porewaters and authigenic minerals in continental margin sediments. Geochim. Cosmochim. Acta 70, 2006-2022.

Schauble, E.A., Rossman, G.R., Taylor, H.P., 2001. Theoretical estimates of equilibrium Fe isotope fractionation from vibrational spectroscopy. Geochim. Cosmochim. Acta 65 2487-2497.

Sharma, M., Polizzotto, M., Anbar, A.D., 2001. Iron isotopes in hot springs along the Juan de Fuca Ridge. Earth Planet. Sci. Lett. 194, 39-51.

Skulan, J.L., Beard, B.L., Johnson, C.M., 2002. Kinetic and equilibrium fractionation between aqueous $\mathrm{Fe}(\mathrm{III})$ and hematite. Geochim. Cosmochim. Acta 66, 2995-3015.

Stumm, W., Morgan, J.J., 1981. Aquatic chemistry: an introduction emphasizing chemical equilibria in natural waters. Wiley, New York. pp. 780 .

Tornos, F., 2006. Environment of formation and styles of volcanogenic massive sulfides: the Iberian Pyrite Belt. Ore Geology Reviews 28, 259-307. 
Van der Lee, J., De Windt, L., 2002. CHESS Tutorial and Cookbook. Updated for version 3.0. Users manual Nr. LHM/RD/02/13. Ecole des Mines de Paris. Fontainebleau, France. pp. 112

Welch, S.A., Beard, B.L., Johnson, C.M., Braterman, P.S., 2003. Kinetic and equilibrium Fe isotope fractionation between aqeous $\mathrm{Fe}(\mathrm{II})$ and $\mathrm{Fe}$ (III). Geochim. Cosmochim. Acta $67,4231-4250$

Weyer, S., Schwieters, J., 2003. High precision Fe isotope measurements with high mass resolution MC-ICP-MS. Int. J. Mass Spectrom. 226, 355-368.

Yu, J.-Y., Heo, B., Choi, I.-K., Cho, J.-P., Ho-Wan Chang, H.-W., 1999. Apparent solubilities of schwertmannite and ferrihydrite in natural stream waters polluted by mine drainage. Geochim. Cosmochim. Acta 63, 3407-3416.
Yamaguchi, K., Johnson, C., Beard, B., Ohmoto, H., 2005. Biogeochemical cycling of iron in the Archean-Paleoproterozoic Earth: constraints from iron isotope variations in sedimentary rocks from the Kaapvaal and Pilbara Cratons. Chem. Geol. 218, 135169

Zettler, L.A., Gómez, F., Zettler, E., Keenan, B.G., Amils, R., Sogin, M.L., 2002. Eukaryotic diversity in Spain's River of Fire. Nature 417, 137. 